\title{
Immigration Detention Reforms: A Small Gain in Human Rights
}

\author{
Savitri Taylor
}

\begin{abstract}
A ustralia's mandatory immigration detention regime came into force in 1994. From the outset, the regime has been vigorously opposed by many civil society organisations and some of its aspects have been criticised by Commonwealth Government agencies such as the Human Rights and Equal Opportunity Commission (HREOC) and the Commonwealth Ombudsman's Office. Increasing media scrutiny since 2000 has also had an effect on public opinion (Taylor, 2001). Both the Labor Government, which introduced the regime, and the Liberal/National Coalition Government, which continued it, have sought to respond to political pressure by progressive mitigation of the harshness of the regime without significant change to the fundamental framework. The Prime Minister's announcement of a number of changes to the mandatory detention regime on 17 June 2005 was the most recent bid to ease political pressure in this way (Howard, 2005).
\end{abstract}

\section{Australia's Immigration Detention Regime}

The aims of the immigration detention regime are: to protect the community from individuals who pose a health, criminal or national security threat; to ensure that non-citizens who are in Australia in breach of immigration laws are available for removal from the country; and to deter prospective unauthorised arrivals (Liberal Party of Australia and Nationals, 2004). However, the design of Australia's immigration detention regime makes it clear that the last stated aim is the primary one. The Migration Act 1958 (Cth) mandates the detention of 'unlawful noncitizens' (those entering Australia without a valid visa) until they leave or are granted a visa. Persons entering Australia on any type of valid visa and subsequently apply for a substantive visa are usually eligible for a so called 'bridging visa', which gives a person the status of 'lawful non-citizen' and allows that person to be at liberty with protection from removal from Australia pending determination of the visa application. In contrast, unauthorised arrivals are ineligible for a bridging visa except in very limited circumstances. If they apply for a substantive visa, they are usually kept in immigration detention, pending determination of the application (and pending removal if unsuccessful).

The deterrence aim is freely acknowledged in the rhetoric of Australia's federal politicians (Vanstone, 2005a:35; Dodson, 2005). However, it is not officially acknowledged by Australia in any forum in which the international legality of its immigration detention regime is under consideration (see, for 
example, HREOC, 2004:210). This is because the first two aims of immigration detention are legitimate under international law, but the last is not (Taylor, 1998). Detaining unauthorised arrivals regardless of the merits of their particular situation for the purpose of deterring others from following in their footsteps is considered illegitimate for one very simple reason. It involves treating human beings as mere means to an end and is, therefore, a repudiation of the fundamental premise of international human rights law, which is the equal worth of every human being.

\section{Human Rights Implications of Mandatory Detention}

Australia is a party to the International Covenant of Civil and Political Rights (ICCPR). Article 9(1) of the ICCPR provides that no one shall be subject to 'arbitrary' detention. Detention is 'arbitrary' if it is not permitted by domestic law or is not a necessary and proportionate means of achieving a legitimate end. Since deterrence is not considered to be a legitimate aim of immigration detention by the international community, the use of detention for that purpose would be 'arbitrary' and in breach of article 9(1). While community protection and availability for removal are considered to be legitimate purposes, detention for those purposes must still be a necessary and proportionate means of achieving the purposes. The only way to ensure that the requirements of necessity and proportionality are met is for detention decisions to be made on a case-by-case basis. The 'necessary' criterion is satisfied if it can be shown that there is no less restrictive means of achieving the end in question in the particular case. Satisfaction of the 'proportionate' criterion requires demonstration that the importance to society of the end to be achieved by detention outweighs the importance to the individual of physical liberty and the negative impact on the individual of deprivation of liberty. It is, of course, almost impossible to overstate the importance to the individual of physical liberty. Since the negative impact of detention on the individual tends to increase as the duration of detention increases, duration of detention is a relevant factor in assessing proportionality. The longer the period of detention, the more difficult it becomes to describe the detention as a proportionate means of achieving any legitimate end. Further, there are some especially vulnerable individuals for whom detention can be expected to be particularly harsh and this, too, is a factor in assessing proportionality.

Pursuant to the Optional Protocol to the ICCPR Australia has recognised the competence of the UN Human Rights Committee 'to receive and consider communications from individuals' who claim to be victims of ICCPR violations by Australia. In three recent cases involving complaints by immigration detainees (C v Australia; Baban v Australia; Bakthyari v Australia) the Human Rights Committee found that even if immigration detention was initially justified, the Australian Government had failed to justify continued detention 'in light of the passage of time and intervening circumstances.' In particular, the Human Rights Committee found that the Australian Government had not demonstrated 'there were not less invasive means' for ensuring the complainants were available for removal, 'for example, the imposition of reporting obligations, sureties or other 
conditions'. In all three cases, the Committee was accordingly of the view that detention had been arbitrary and constituted a violation of article 9(1) of the ICCPR. The Human Rights Committee also considered whether Australia was in violation of article $9(4)$ of the ICCPR which provides that:

Anyone who is deprived of his liberty by arrest or detention shall be entitled to take proceedings before a court, in order that court may decide without delay on the lawfulness of his detention and order his release if the detention is not lawful.

The Australian Government argued that adequate compliance with article 9(4) was achieved by the fact that an Australian court could order release if immigration detention was found to be unlawful under Australian law. However, in all three cases a majority of the Human Rights Committee took the view that the term 'lawfulness' in article 9(4) refers to 'lawfulness' under international law as well as domestic law. They found Australia to be in violation of article 9(4) since no Australian court had power to consider whether there was substantive justification for continued detention under international law, let alone order release in the absence of such justification.

In summary, the three main aspects of the mandatory detention regime that are of human rights concern are: the plight of especially vulnerable individuals; the problem of prolonged or indefinite detention; and the absence of independent review.

\section{Situation of Especially Vulnerable Individuals}

This section explores whether the recent immigration detention reforms have resulted in human rights gains for especially vulnerable individuals.

\section{Alternative Places of Detention and Residence Determinations}

Section 5(1) of the Migration Act provides that a person is in immigration detention' if held by or on behalf of a person who is authorised by the Minister in an immigration detention centre (IDC) or other place listed in the section or 'another place approved by the Minister in writing'. Therefore, even before the June 2005 reforms, one option for dealing with vulnerable individuals ineligible for a bridging visa, but whose needs could not be met in an IDC, was to arrange a more suitable place for their detention. In practice, alternative detention was also subject to the detainee meeting health and character requirements and being assessed as not presenting a high risk of absconding or other management problems (Department of Immigration ${ }^{1}$, 2002:paras 5.2.1, 5.2.6 and 6.1.2).

1 Formerly (before January 2006) Department of Immigration, Multicultural and Indigenous Affairs (DIMIA), now Department of Immigration and Multicultural Affairs (DIMA). 
Moreover, the use of alternative places of detention was relatively rare prior to August 2001.

A significant step towards more extensive use of alternative places of detention was achieved with the establishment of a Residential Housing Project (RHP) near the Woomera IDC in August 2001 (HREOC, 2004:143) at a time of great political pressure (see Taylor, 2001). The Woomera RHP, and another RHP established in Port Hedland, were later decommissioned due to reduced numbers in detention, but can be re-commissioned if circumstances change (DIMA, 2005a). At present there is one operational RHP with a maximum capacity of 40 located at Port Augusta, with one adult male in residence (DIMA, 2006). An RHP of similar capacity will open in Sydney in mid-2006 and an RHP with a capacity of 12 residents in Perth in late 2006 (Vanstone, 2006). Examples of other alternative places of detention include foster care homes (primarily used for unaccompanied minors) and accommodation made available pursuant to community care arrangements between DIMA and non-government organisations (NGOs)(DIMA, 2002:paras 6.4.1-6.4.5 and 6.6.1-6.6.4).

Prior to the June 2005 reforms, officers of the Department of Immigration were instructed that unlawful non-citizen women and children, unable to be released from detention relatively quickly, 'should as a matter of priority be given the option' of placement in an RHP (DIMA, 2002:para 5.2.1). They could also consider giving 'other detainees with special needs better suited to management in a housing environment, the option of residing in a RHP' (para 5.2.6). Of course, placement in an RHP was subject to a place actually being available.

According to the same departmental instructions (para 5.1.2):

The purpose of a RHP is to permit detainees to live in a more domestic environment that is less structured than an [IDC], and to permit them a greater degree of autonomy over their own lives, while they remain formally in detention and available for processing and removal from Australia if necessary.

However, because adult males were not considered for RHP placement, families were placed in the difficult position of choosing between better conditions of detention for eligible family members and family unity (HREOC, 2004:145). Also within RHPs detainees had only restricted freedom of movement and were subjected to constant surveillance and a high degree of supervision. As one child who was detained at the Woomera RHP observed (quoted in HREOC, 2004:160):

The [detention] centre has its own problems and the housing project has also its own problems. Like I think both are equal. Just here is like ... the shape is different.

Prior to the June 2005 reforms, DIMA felt that more use of the community care alternative detention option could have been achieved with greater willingness by NGOs to enter into the necessary arrangements (Vanstone, 2005b). NGOs had, in fact, two good reasons to be wary of entering such arrangements. 
One was inadequate resources. According to Melbourne's Asylum Seeker Resource Centre (Karapanagiotidis, 2005):

The Community Detention Model places the burden for the care of such families onto what are usually non-government funded asylum seeker welfare agencies. [DIMA] rarely will fund the medical care, housing or material aid needed by asylum seekers despite them legally still being in detention and thus in their care. This has placed great pressure on agencies to meet the needs of asylum seekers who often have medical needs that require specialist care and management, income to support their family and stable housing to ensure their safety and well-being.

The other main reason for NGO wariness was the Migration Act's requirement for nomination of not only a place of detention but also a person responsible for the detention. Serving as jailers was not a comfortable role for these organisations because of the potential conflict between serving the welfare needs of the client and discharging responsibilities under the Migration Act. To overcome this obstacle, a new subdivision entitled 'Residence Determinations' was inserted into the Migration Act as part of the June 2005 reforms (Vanstone, 2005b). The new provisions give the Minister for Immigration a personal and non-compellable power exercisable 'in the public interest' to make a determination that a specified person is to reside in a specified place and comply with certain conditions instead of being detained in the manner usually required by the Migration Act. According to the Government, the purpose of the power is to enable the detention of families with children, unaccompanied minors and 'adults presenting with exceptional circumstances, to take place in the community where conditions are set to meet their individual circumstances' (DIMA, 2005b; Commonwealth Ombudsman, 2005). Persons subject to residence determinations are 'free to move about in the community without being accompanied or restrained by an officer under the act' (McGuaran, 2005). Nevertheless, most provisions of Migration Act continue to apply to such a person 'as if the person were being kept in immigration detention' under section 189. Those subject to residence determinations are advised by DIMA, that in order to prove their status, if for example, they are picked up by police, they should carry with them at all times a letter provided to them by DIMA which sets out the residence determination arrangement as well as Departmental contact details (DIMA, 2005c:111).

The residence determination model of community detention is a considerable improvement on the alternative place of detention model. Not only are NGOs relieved of the burden of acting as jailers, they also appear to have been relieved of the burden of supporting detainees. DIMA, through the Australian Red Cross (ARC), is funding the provision of income support, accommodation and health care for persons subject to residence determinations (Clutterbuck, 2005:69; Greco, 2005:40). Moreover, ARC in partnership with leading welfare agencies such as the Brotherhood of St Laurence (BSL), St Vincent de Paul, the Salvation Army, 
Anglicare and Uniting Care, is developing and implementing a comprehensive and coordinated approach to working with persons subject to residence determinations, including ongoing needs assessment and case management as well as service delivery (BSL, 2005:2; Greco, 2005:38).

While the residence determination model of community detention will certainly result in human rights gains for persons detained pursuant to such determinations, there is no actual compulsion on the Minister to use this form of community detention for a particular individual as opposed to declaring an alternative places of detention for that individual. However, the Government's intention is that, in future, families (not only mothers and children but also fathers) will be detained in RHPs until primary assessment of visa applications is complete and will then be detained in the community under a residence determination unless community detention conditions are breached or removal is imminent (McGuaran, 2005). At 3 February 2006, there were 101 people, including 54 children, subject to residence determinations (DIMA, 2006).

\section{Release from Detention on Bridging E Visa}

As previously mentioned, a bridging visa is the device used in the Migration Act to avoid detention for authorised arrivals not holding a substantive visa. As a general rule, unauthorised arrivals are not eligible for a bridging visa. However, in an exception to the general rule, prescribed classes of unauthorised arrivals are theoretically eligible for the grant of a Bridging E Visa. The prescribed classes include protection visa applicants aged less than 18 or more than 75 or who cannot properly be cared for in a detention environment because of 'a special need (based on health or previous experience of torture or trauma)' (Migration Regulations). These categories of person are eligible for a Bridging E Visa, subject to there being adequate arrangements for their care or support in the community and subject to health, character and security requirements.

Although the relevant provisions have been in place since 1 September 1994, only a few unauthorised arrivals with the specified vulnerabilities have been granted bridging visas (HREOC, 2004:182-97). However, the fact that on 22 June 2005 there were 8 children and 24 special need individuals in the community who had been released on a bridging visa under the relevant provisions (DIMA, 2005d) may now indicate a greater readiness by DIMA to use these provisions.

Use of the provisions is not unproblematic. There are difficulties in meeting the requirement that there be adequate arrangements for their care or support in the community. For adults, the adequate care and support requirement arises from the fact that most persons released on a Bridging $E$ Visa are denied both work rights and social assistance entitlements (Burn and Reich, 2005:162). Unfortunately, the NGOs that enter into care arrangements with DIMA do not have the resources to meet the basic needs of those released, especially over the longer term. Although DIMA recognises this and is willing to consider NGO requests to assist with living allowances, medical and health costs, administration costs and the like on a case-by-case basis (DIMA, 2005e), the fact remains that it does not underwrite 
these costs fully or as a matter of course. For example, DIMA was contributing to the costs of maintaining only 7 of the 24 individuals in the community on 22 June 2005 who had been released on a bridging visa on special need grounds (DIMA, 2005f). Moreover, DIMA considers its duty of care to be at an end once release on a bridging visa has occurred. Thus bridging visa holders have no recourse if care arrangements prove inadequate or unsustainable as they often do (Domicelj, 2005:30). A 2003 study published by the Asylum Seeker Project Hotham Mission (2003:4) found that asylum seekers on Bridging E Visas 'live in abject poverty', experience 'high levels' of mental health problems, 'a general reduction in overall health', and 'high levels of family breakdown'.

On a more positive note, DIMA is currently conducting a review for the purpose of making recommendations to the Minister on how greater flexibility in the availability of, and conditions attached to, bridging visas can be introduced so that DIMA officers can respond appropriately to the needs of particular individuals without compromising achievement of the Government's immigration control objectives (McMahon, 2005).

\section{Exercise of Section 195A Migration Act}

Another serious failing of the immigration detention regime (prior to the June 2005) was the inability to grant a bridging visa to an unauthorised arrival falling outside the prescribed classes, whether or not such a grant was an appropriate response to that individual's circumstances. Since 29 June 2005 the Minister for Immigration has had a personal and non-compellable power under section 195A of the Migration Act to grant a visa to a person who is in detention under section 189, if 'the Minister thinks that it is in the public interest to do so'. In exercising this power, the Minister may grant any visa deemed appropriate, even if the person does not satisfy the specified criteria for granting that visa. This means, among other things, that the Minister can grant a bridging visa to an unauthorised arrival (outside the prescribed classes) for whom detention would have a harsher than normal impact. Moreover, since the Minister may grant any visa, the granted bridging visa could be of a class that carries work and social assistance entitlements.

\section{Length of Detention}

Only 25 per cent of all unlawful non-citizens detected by DIMA are taken into immigration detention - an even lower (7 per cent) proportion of all unlawful non-citizen women and children is taken into detention (Vanstone, 2005c). This is because most unlawful non-citizens enter Australia on a valid visa and are usually, therefore, eligible for a bridging visa after becoming unlawful. The problem is that a significant proportion of those who are taken into immigration detention remain in detention for long periods of time. At 23 September 2005, there were 748 immigration detainees of whom 116 had been in detention for between one and two years and 92 had been in detention for two years or more (DIMA, 2005g). 
As a result of the June 2005 reforms, the number of long-term detainees is the lowest it has been in at least the last four years (DIMA, 2005g).

\section{Processing Time Limits}

To minimise the time unauthorised arrivals spend in detention pending the processing of protection visa applications, DIMA and the Refugee Review Tribunal (RRT) have long given priority to applications by immigration detainees and respectively have had processing time targets for these cases of 42 days and 70 days (DIMA, 2004:70; RRT, 2004:23-24). Since December 2005 the Migration Act also sets out legislated processing 'time limits' of 90 days each by DIMA and by the RRT. Non-compliance with the 'time limits' will trigger reporting requirements by the Department to the Minister and by the Minister to Parliament, but, as the Government emphasises, it 'will not give rise to a right to the issuing of a visa or release from detention' (McGuaran, 2005). It is also important to note that this reform doesn't actually address the main factors which delay processing time of many applications. These factors are the inordinate amount of time taken by the Australian Security Intelligence Organisation to complete security checks (Law Institute of Victoria, 2005:21-2) and the inability of individuals with non-refugee protection claims to get those claims addressed until after they have received a negative decision from the RRT (Law Society of South Australia, 2005:13-14).

\section{Release on Bridging Visa}

Since 1994, the Minister for Immigration has had the power under section 72(1)(c) of the Migration Act to determine that an otherwise ineligible person is eligible to apply for a bridging visa if that person has been in immigration detention for more than six months since lodging a protection visa application without a primary decision having been made, and the Minister considers a determination to be in the public interest. The power is personal to the Minister and its exercise is noncompellable. At the time of writing, only four individuals had ever benefited from the exercise of this power.

The Australian Government often asserts that the long-term detainee population consists wholly of individuals who are not entitled to any substantive visa but are nevertheless trying to avoid removal by, among other things, misusing Australia's legal processes. This is simply untrue. In the past two years there have been over 100 cases of long-term detainees eventually being granted protection visas (Rural Australians for Refugees, 2005; Georgiou, 2005).

Quite aside from the merits of their case, however, some unlawful noncitizens are for practical reasons unable to depart Australia. The Migration Regulations have been amended with the stated purpose of ameliorating the plight of some of these individuals. Since 16 June 2005, persons in immigration detention whose 'removal from Australia is not reasonably practicable' for the time being have been eligible for the grant of a Removal Pending Bridging Visa (RPBV), provided the Minister is satisfied that the person 'will do everything 
possible to facilitate' their removal from Australia and any visa applications (with specified exception) have been finally determined. They also have to meet character and national security requirements. Moreover, only detainees invited to do so by the Minister for Immigration are able to apply for a RPBV. As at 14 July 2005 the Minister had invited 58 individuals to apply for a RPBV and 42 of them had taken up the invitation (Cobb, 2005). However, as at 13 February 2006 there had only been a total of 31 grants of RPBVs (Mann, 2006)

If granted, a RPBV enables the holder to remain at liberty in the community until removal from Australia becomes reasonably practicable. Importantly, the holders of RPBVs are given some social assistance entitlements and have the right to work.

\section{Exercise of 195A Migration Act Power}

As already mentioned, the new section 195A of the Migration Act gives the Minister a personal and non-compellable power to grant a visa to a person detained under section 189, if 'the Minister thinks that it is in the public interest to do so'. Thus the Minister is now able to bring any long detention situation to an end by granting the detainee a bridging visa or indeed a substantive visa regardless of whether the person in question meets the usual visa criteria.

\section{Detention Review}

The final aspect of the mandatory detention regime, which has been subject to extensive criticism, is the unavailability of an independent body to review an individual's detention at regular intervals and to order release if detention is not, or ceases to be, 'a necessary and proportionate means of achieving a legitimate aim'. The June 2005 reforms have not changed this.

The Secretary of the Department of Immigration is required by the new Part 8C of the Migration Act to report on the circumstances of a person's detention to the Commonwealth Ombudsman once the detention period reaches two years and at six-monthly intervals thereafter. At 3 February 2006, DIMA had provided an initial report to the Ombudsman on the 152 detainees who had reached the two year mark before 29 June 2005 and provided second reports on the 51 out of those 152 detainees who still remained in detention (Commonwealth Ombudsman, 2006:1). DIMA had also reported on 59 detainees who had reached the two year mark after 29 June 2005 (Commonwealth Ombudsman, 2006:1). As soon as practicable after receiving a report, the Ombudsman is required to assess the appropriateness of the detention arrangements and to provide that assessment to the Minister. The assessment may include any recommendations the Ombudsman thinks fit to include - for example, a recommendation that the person should be held in another form of detention or that the person should be released into the community on a visa. However, the Minister 'is not bound by any recommendations the Commonwealth Ombudsman makes'. The only thing that 
the Minister must do is table a modified version of each assessment in Parliament within 15 sitting days of receiving it.

At 3 February 2006, the Ombudsman had provided a total of 43 assessments to the Minister (Commonwealth Ombudsman, 2006:1). At 9 February 2006 the Minister had tabled 14 assessments together with statements indicating that there had been one removal, four grants of substantive visa and one other release from detention in advance of the Minister receiving the Ombudsman's recommendation. In two cases, release had occurred after receipt of the recommendations but it was not clear that release had occurred because of the recommendations. In the remaining cases the Minister was considering the action recommended by the Ombudsman. It therefore remains to be seen to what degree the Minister will feel politically constrained to give effect to the Ombudsman's recommendations.

On the plus side the Government has provided the Commonwealth Ombudsman with additional funding of \$12.8 million over four years in order to discharge the enhanced supervisory role in relation to immigration detention and other immigration matters (Vanstone, 2005d). In addition, legislation designed to facilitate the Ombudsman's investigative activities commenced in December 2005. On the minus side, the Government has a track record of ignoring recommendations of 'toothless' watchdogs that have thus far attempted to hold the Government accountable for the administration of immigration detention, including recommendations made by the Commonwealth Ombudsman (Taylor, 2000). Another minus is the fact that the detention review mechanism kicks in only after a person has been in immigration detention for two years. As Laurie Ferguson (2005) has pointed out, Cornelia Rau was mistakenly held in immigration detention for ten months not two years, yet the Minister for Immigration (Vanstone, 2005a:23) is on record as saying: 'Can I give an absolute guarantee that the detention of Cornelia Rau did not in any way further damage her condition? Of course I cannot give that guarantee'.

\section{Looking Forward}

Ever since the introduction of the mandatory immigration detention regime, its opponents have suggested alternatives to achieve the legitimate ends without imposing as high a cost on the individuals concerned. The suggested alternatives allow for unauthorised arrivals to be detained as a matter of course for a brief initial period in which identity, health, character and national security checks can be undertaken. Upon expiry of the initial detention period, the suggested alternatives require continued detention to be justified on the facts of the particular case as a necessary and proportionate means of ensuring community protection or availability for removal. Further they require that an individual's detention be reviewed by a court at frequent intervals, with the court empowered to order release if it finds that detention has become unnecessary or disproportionate. The suggested alternative models require that all less restrictive means of achieving legitimate ends, such as release subject to reporting obligations or provision of 
surety or other conditions, be found unable to achieve the same ends in a particular case, before a finding can be made that detention is necessary. The more fully developed alternative models include a role for alternative places of detention to deal with those individuals who need not, or should not, be subjected to the full rigours of an IDC environment, but who for legitimate reasons cannot be released from detention either.

In addition to these features, the Reception and Transitional Processing (RTP) Model developed by the Justice for Asylum Seekers Alliance also contemplates the establishment of a case management system administered by an independent service provider. This includes the assignment of a case worker to each asylum seeker with the specific role of providing information, advice and assistance to the asylum seeker from the time of arrival until a substantive visa is granted or removal is affected. Among other things, the case worker would counsel the asylum seeker throughout the determination process to prepare that person for all possible outcomes, including removal from Australia in the event the claim is rejected. The premise is that the goal of ensuring that persons with no right to be in Australia are available for removal can be achieved just as well by helping individuals to accept a removal decision as by employing detention and other coercive means. The RTP Model is inspired by the model used in Sweden which has in fact been highly successful in procuring the voluntary return of rejected asylum seekers (Justice for Asylum Seekers Alliance, 2002:25).

In summary, human rights compliant alternatives to mandatory detention already exist on paper. The task which remains to be accomplished is that of turning the theoretical alternatives into actual policy. One positive outcome of the Cornelia Rau scandal is that this may conceivably happen. DIMA, in partnership with community sector agencies, is presently developing a community care model to be piloted in Sydney and Melbourne with 400 to 500 selected immigration detainees and others of 'particular compliance interest' (DIMA, 2005h: 6-7; DIMA, 2005c:66; Correll, 2006). At the time of writing the 12 month pilot was about to commence (Correll, 2006). According to DIMA, the community care model will be an augmentation of a wider case management framework being rolled out across its service delivery network to 'holistically' manage clients, 'particularly those who are vulnerable or have complex circumstances' (DIMA, 2005c:66). DIMA says 'the expectation is that case management would include managing the transition to settlement or removal (DIMA, 2005c:66). Entrusting the case management function to DIMA officers rather than an independent service provider as called for by the RTP model is problematic. There is potential for officers to face serious conflict of interest if they are required to discharge compliance and welfare duties simultaneously. Leaving aside this reservation, however, the community care model pilot itself is welcome as it will additionally involve the provision of services 'based on individual need which may include housing, assistance with living needs, counselling, medical and mental health intervention' (DIMA, 2005c:66) while DIMA decisions are made regarding removal, or where appropriate, temporary or permanent settlement' (DIMA, 2005h:6-7). The Government will consider wider implementation of the model 
once the pilot has been assessed (DIMA, 2005h:7). While the mandatory detention policy continues to apply, the changes that have been implemented do represent a small improvement from a human rights perspective and those being considered hold out the possibility of significant improvement in the future.

\section{References}

Asylum Seeker Project Hotham Mission (2003), Welfare Issues and Immigration Outcomes for Asylum Seekers on Bridging Visa E: Research and Evaluation, Melbourne, November.

Baban v Australia (2003), Communication No. 1014/2001, 18 September.

Bakhtiyari v Australia (2003), Communication No. 1069/2002, 29 October.

Brotherhood of St Laurence (2005), 'Submission to the Inquiry into the Operation and Administration of the Migration Act 1958', http://www.aph.gov.au/senate/committee/ legcon_ctte/migration/submissions/sub175.pdf.

Burn, J. and S. Reich (2005), The Immigration Kit, $7^{\text {th }}$ ed, The Federation Press, Sydney.

C v Australia (2002), Communication No 900/1999, 13 November.

Clutterbuck, M. (2005), Evidence to Inquiry into the Operation and Administration of the Migration Act 1958, Official Committee Hansard, Senate Legal and Constitutional References Committee, 27 September:64-73.

Cobb, J. (2005), Parliamentary Debates, House of Representatives, 7 September:153-154.

Commonwealth Ombudsman (2005), ‘Briefing for Dr Savitri Taylor’, 5 December (Copy on file with author).

Commonwealth Ombudsman (2006), Immigration Bulletin 7,3 February, http://www.comb.gov.au/news_current_issues/media_releases/bulletin7_immigration_matt ers_030206.pdf.

Correll, B. (2006), 'Evidence at Additional Estimates Hearing’, Proof Committee Hansard, Senate Legal and Constitutional Legislation Committee, 13 February:13.

Department of Immigration (2002), 'Migration Series Instruction 371: Alternative Places of Detention'.

Department of Immigration (2004), Annual Report 2003-04, Canberra.

Department of Immigration (2005a), 'Fact Sheet 83: Residential Housing Projects', 24 May, http://www.immi.gov.au/facts/83rhps.htm.

Department of Immigration (2005b), ‘Briefing for Dr Savitri Taylor’, 6 December (Copy on file with author).

Department of Immigration (2005c), 'Answer to Question Taken on Notice at Senate Legal and Constitutional References Committee Inquiry into the Administration of the Migration Act 1958', 5 December, http://www.aph.gov.au/senate/committee/legcon_ ctte/migration/qon/05dec-dimia2.pdf. 
Department of Immigration (2005d), ‘Answer to Question 183 Taken on Notice’, Senate Legal and Constitutional Legislation Committee, Budget Estimates Hearing, 25-27 May, http://www.aph.gov.au/senate/committee/legcon_ctte/estimates/bud_0506/dimia/a175186.pdf.

Department of Immigration (2005e), 'Answer to Question 15 Taken on Notice', Senate Legal and Constitutional References Committee Inquiry into the Administration of the Migration Act 1958, 11 October, http:/www.aph.gov.au/senate/committee/legcon_ ctte/migration/qon/11oct-dimia.pdf.

Department of Immigration (2005f), ‘Answer to Question 163 Taken on Notice’, Senate Legal and Constitutional Legislation Committee Budget Estimates Hearing 25-27 May, http://www.aph.gov.au/senate/committee/legcon_ctte/estimates/bud_0506/dimia/a151175.pdf.

Department of Immigration (2005g), 'Answer to Question 8 Taken on Notice', Senate Legal and Constitutional References Committee Inquiry into the Administration of the Migration Act 1958, 25 October http:/www.aph.gov.au/senate/committee/legcon_ ctte/migration/qon/25oct-dimia.pdf.

Department of Immigration (2005h), 'Implementation of the Recommendations of the Palmer Report of the Inquiry into the Circumstances of the Immigration Detention of Cornelia Rau', September http://www.immi.gov.au/current-issues/palmer/palmerresponse.pdf.

Department of Immigration (2006), 'Immigration Detention Facilities', 3 February, http://www.immi.gov.au/detention/facilities.htm.

Dodson, L. (2005), 'Beazley Rules Out Conscience Vote on Detention Bill', Sydney Morning Herald, 26 May:4.

Domicelj, T. (2005), Evidence to Inquiry into the Operation and Administration of the Migration Act 1958, Official Committee Hansard, Senate Legal and Constitutional References Committee, 28 September:26-38.

Ferguson, L. (2005), Parliamentary Debates, House of Representatives, 22 June: 58.

Georgiou, P. (2005), 'Why We Need a New Policy on Refugees’, The Age, 26 May:19.

Greco, S. (2005), Evidence to Inquiry into the Operation and Administration of the Migration Act 1958, Official Committee Hansard, Senate Legal and Constitutional References Committee, 27 September: 32-43.

Howard, J. (2005), 'Immigration Detention', Media Release, 17 June, http://www.pm.gov.au/news/media_releases/media_Release1427.html.

Human Rights and Equal Opportunity Commission (2004), A Last Resort?, Report of the National Inquiry into Children in Immigration Detention, Sydney.

Justice for Asylum Seekers Alliance (2002), 'Alternative Approaches to Asylum Seekers: Reception and Transitional Processing System', http://asp.hothammission.org.au /index.cgi?tid=22. 
Karapanagiotidis, K. (2005), ‘ASRC’s Concerns Regarding Community Detention’, 20 June, http://backend.ewock.com/ewocksql/asp/index.asp?ID=166\&Action=News\& IDNewsItem $=590$.

Law Institute of Victoria (2005), 'Submission to Inquiry into the Operation and Administration of the Migration Act 1958', http://www.aph.gov.au/senate/committee/ legcon_ctte/migration/submissions/sub206.pdf.

Law Society of South Australia (2005), 'Submission to Inquiry into the Operation and Administration of the Migration Act 1958', http://www.aph.gov.au/senate/committee/ legcon_ctte/migration/submissions/sub110.pdf.

Liberal Party of Australia and Nationals (2004), 'The Howard Government Election 2004 Policy: Stronger Border Protection', http://parlinfoweb.aph.gov.au/piweb/Repository1/ Library/partypol/BLXD60.pdf.

Mann, N. (2006) Evidence at Additional Estimates Hearing, Proof Committee Hansard, Senate Legal and Constitutional Legislation Committee, 13 February:66.

McGuaran, P. (2005), 'Migration Amendment (Detention Arrangements) Bill 2005 Second Reading', Parliamentary Debates, House of Representatives, 21 June:55-58.

McMahon, V. (2005), Evidence at Budget Estimates Hearing, Official Committee Hansard, Senate Legal and Constitutional Legislation Committee, 25 May:42-43.

Refugee Review Tribunal (2004), Annual Report 2003-2004.

Rural Australians for Refugees (2005), 'Mandatory Detention and Temporary Protection: Petro Georgiou's Private Member's Bills, Myths and Facts', Fact Sheet, http://www.ajustaustralia.com/resource.php?act=attache\&id=76.

Taylor, S. (2001), ‘Achieving Reform of Australian Asylum Seeker Law and Policy’, Just Policy 24:41-54.

Taylor, S. (2000), 'Protecting the Human Rights of Immigration Detainees in Australia', Sydney Law Review 22(1):50-92.

Taylor, S. (1998), 'Weaving the Chains of Tyranny', Law in Context 16(2):1-33.

Vanstone, A. (2005a), Parliamentary Debates, Senate, 10 May.

Vanstone, A. (2005b), Parliamentary Debates, Senate, 23 June:71-77.

Vanstone, A. (2005c), Parliamentary Debates, Senate, 13 October:48.

Vanstone, A. (2005d), 'Palmer Implementation Plan and Comrie Report', Media Release, 6 October, http://www.minister.immi.gov.au/media_releases/media05/v05119.htm.

Vanstone, A. (2006), 'Vanstone Builds on Commitment to Alternative Detention', Media Release, 2 February, http://www.minister.immi.gov.au/media_releases/media06/v06013. htm. 